\title{
SOBRE EL CONCEPTO DE MÍMESIS EN LA ANTIGUA GRECIA
}

\section{GIOVANNi GUTIÉRREZ CANALES Estudios Internacionales. Universidad de Chile. Chile}

Resumen: En forma sucinta, aunque no por ello menos rigurosa, este trabajo intenta dar cuenta de los antecedentes históricos del concepto griego mímesis, aportando insumos para la discusión académica. Se destacan aquí los orígenes mágico-religiosos del término, tiempos en que tenía un significado más rico y complejo que la simple noción de representación o semejanza que la modernidad posteriormente masificó.

Palabras clave: Mímesis - Transfiguración - Encarnación - Representación Ilusión - Verosímil - Propedéutica.

\section{ON THE CONCEPT OF MIMESIS IN THE ANCIENT GREECE}

\begin{abstract}
Succinctly but no less rigorously, this work tries to explain the historical precedents of the Greek concept of mimesis, tackling different perspectives of the academic discussion. According to the magical-religious origin of this word, we must keep in mind that its early meaning was much richer and more complex than our massive and modern notion of resemblance or representation.
\end{abstract}

Keywords: Mimesis, Transfiguration, Incarnation, Representation, IllusionVerisimilar, Propaedeutic.

Recibido: 22.12.15 - Aceptado: 14.03.16

\section{Correspondencia: Giovanni Gutiérrez Canales}

Email: sandinog@u.uchile.cl

Licenciado en Teoría e Historia del Arte, Universidad de Chile. Licenciado en Lengua Inglesa, Universidad Arturo Prat. Estudiante del Magíster en Estudios Internacionales, Universidad de Chile. Corporación Cultural "Ars-Vitae". Gorbea 1953, dpto.502, Santiago-Chile. (56-22) 6223791 / cel. +56-9-3404750. 


\section{1.- Mímesis como encarnación.}

Tmitación y representación son los más recurridos sinónimos que se

han empleado para sustituir el sentido del término mímesis que Platón y Aristóteles utilizaron en sus reflexiones sobre la producción artística. Sin embargo, este concepto formaba parte de una antigua tradición ritual en el mundo griego, que antecedía por siglos las propuestas de ambos filósofos, y que en sus orígenes cargaba con un significado más rico y complejo que la simple noción de reproducción o copia ${ }^{1}$.

Mimesis aparece junto a las primeras fiestas agrarias que los antiguos griegos realizaban para agradecer a sus dioses por la fecundidad de la tierra y la cosecha obtenida en los campos. Según los expertos, el vino que se consumía en estas celebraciones era una infusión embriagante extremadamente potente, pues con su libación pretendían llegar a sentir la presencia de las deidades honradas. Al respecto, los profesores Carl Ruck (USA, 1935-), Albert Hoffman (Suiza, 1906-2008) y Robert Gordon (USA, 1898-1986) señalan:

"Sabemos de vinos tan fuertes que tenían que ser diluidos en veinte partes de agua, y requerían al menos de ocho partes más para ser bebidos sin problemas. Su consumo sin dilución podía provocar daño cerebral permanente e incluso la muerte.Diferentes vinos producían diferentes síntomas, desde insomnio hasta alucinaciones, debido a que en la ceremonia de dilución podian añadirsele ungüentos, especias y hierbas con propiedades psicotrópicas bien conocidas" ${ }^{2}$.

El consumo de este vino propiciaba una alteración de la personalidad de los feligreses más sedientos, algunos de los cuales, alcanzando un estado de éxtasis, actuaban como si sus cuerpos estuvieran poseídos por una entidad sobrehumana. El ser poseso fue denominado mimós y su experiencia extática respectiva fue designada mímesis, palabra que en estos primeros tiempos tuvo mucha más relación con nuestro concepto de encarnación que con una simple imitación. Esta es al menos, la opinión del profesor Francisco Rodríguez

1 Cf. Bozal (1987), pp.65-66.

2 Ruck et $\mathrm{Al}$ (2008), pp. 51-52.

98 
(España, 1922- ), a la que también se suma el profesor Valeriano Bozal (España, 1940- ):

“"Mímesis» deriva de «mimós»y «mimeisthai», términos que se refieren originariamente al cambio de personalidad que algunos fieles experimentaban en ciertos rituales, cuando sentian que en ellos se encarnaban seres de naturaleza no humana-divina o animal-o seres de otro tiempo. "Mimeisthai» no es tanto imitar como representar, encarnar a un ser alejado de uno"3.

Aquí la mímesis -parafraseando al profesor Bozal- se produce en el curso de una acción ritual con condiciones materiales específicas. Los elementos de sugestión eran fundamentales para otorgar veracidad al fenómeno, ya que los participantes consideraban que el mimós era un verdadero nexo con el mundo de los dioses. En la fiesta, y gracias a esta suerte de encarnación, los hombres que otrora escuchaban relatos fantásticos sobre el panteón olímpico, pueden llegar a ser los dioses mismos: de allí la contundencia de sus efectos ${ }^{4}$.

El concepto de mímesis entendido como encarnación puede vislumbrarse en el «Himno a Apolo Delio», atribuido al poeta Homero aunque fechado hacia el siglo VII a.C. Se trata de la primera referencia directa que tenemos del término. El autor nos relata un suceso extraordinario, que de acuerdo a sus propias palabras, "por siempre gozará de fama"5. En la pequeña isla de Delos existía un templo dedicado al dios Apolo custodiado por un grupo de doncellas. Cuando los fieles devotos entraban en el recinto para venerar al dios,

"las muchachas, luego de honrar con alabanzas a Apolo, a Leto y a la certera flechadora Artemisa, entonan himnos evocando las hazañas del pasado, y pueden mimetizar la voz y las actitudes de todos los hombres, al punto de confundir al oyente sobre quién realmente se encuentra hablando. Tal es la excelencia de su dulce canto"6.

3 Bozal, op.cit., p.70.

4 Cf. Ibid., p.72.

5 Homero (1914), vv. 155-156.

6 Homero (1914), vv. 160-165. 
La veneración previa que las doncellas realizan a los dioses da cuenta del cariz religioso que tiene su acción mimética. No estamos en presencia de una simple imitación, sino de la encarnación de cualidades identitarias de una alteridad sobre cuerpos diferentes y al interior de un templo. Es una suerte de transfiguración que sorprende precisamente por su carácter inédito y mágico. Intentemos dilucidar esta cuestión analizando algunos aspectos de la poesía en Grecia.

Debemos recordar que la mayoría de la población que vivía en torno al Mediterráneo durante la Antigüedad era analfabeta ${ }^{7}$. La lectura era desarrollada por unos cuantos individuos provenientes de la clase alta que tenían los recursos y el tiempo suficientes como para dejar de practicar la agricultura o algún otro oficio indispensable para la subsistencia y dedicarse al estudio de los signos. El conocimiento es poder y ha sido celosamente restringido desde antaño: la tradición oral cumplió entonces un importante rol como sistema de transmisión cultural.

Fue en este contexto donde surgió la figura del aedo, es decir, del cantautor popular. Los aedos recitaban sus composiciones en los banquetes o reuniones sociales, y en general, allí donde fueran bien recibidos. La relevancia que su oficio tuvo fue muy significativa para el mundo antiguo, porque al describir los defectos y virtudes que tenían sus personajes, y los implacables castigos que desde el Olimpo recaían sobre quienes desafiaban los designios divinos, iban propagando paradigmas éticos a su auditorio. En este sentido, y a modo de ejemplo, recordemos que el mismo Platón reconocía que los versos del poeta Homero habían educado por generaciones a todos los griegos ${ }^{8}$.

Apenas iniciaban la declamación de sus versos, los aedos invocaban la presencia de las Musas. Según la tradición, estas diosas otorgaban al poeta acceso a una memoria histórica y situaciones específicas que constituían la base de su narración ${ }^{9}$. Como casi siempre se trataba de sucesos remotos que muchas veces acontecían allende el territorio griego, la autoridad y veracidad del relato estaba garantizado precisamente por la invocación de estas deidades. Ellas comparecían frente a todos mediante las palabras del poeta, y la evidencia

7 Cf. Chic (2009), p.125.

8 Cf. Jaeger (2000), p.48.

9 Cf. Bochetti (2006), p.39. 
de ello radicaba en la cantidad de datos atávicos que contenía la trama. Sin el celeste auxilio de los dioses, un mortal común no tenía cómo acceder a esta información. Luego de su invocación, la propia Musa se convierte en el hablante lírico de la trama ${ }^{10}$.

Dando cuenta del dinamismo que posee el lenguaje, el poeta Teognis de Megara, casi trescientos años después de Homero, ya utilizaba el verbo mimeisthai con un cariz diferente. Defendiéndose de las críticas que recibía por parte de sus conciudadanos, Teognis declaró: "buenos y malos me critican, pero ninguno de estos ignorantes me ha podido mimetizar" ". El sentido de mímesis que Teognis ocupa en esta sentencia tiene más relación con igualar en logros que con imitarlos como fiel copia. Lo importante no es que el resto llegue a escribir exactamente las mismas obras, ni posea las mismas actitudes que el poeta tiene frente a los demás. Antes bien, se trata de que exista algún otro que pueda llegar a ser su par en dignidad.

Fue Sócrates quien durante el siglo V a.C., definió la mímesis como una representación aparente y cuestionó su inmanencia sagrada. Así por lo menos lo consignan Jenofonte y Platón. Aristóteles, por su parte, añadió perspectivas diferentes y observaciones muy atendibles como luego veremos.

\section{2.- La acción mimética para Sócrates.}

En «República», uno de los diálogos platónicos más importantes, Sócrates define la quintaesencia de la mímesis estatuyendo una jerarquía ontológica. En el décimo capítulo, el texto nos describe la producción de camas diferentes, una labrada por un carpintero, otra por un pintor ${ }^{12}$. La cama del carpintero está hecha a partir de la idea o noción de cama que su creador concibe. Esta abstracción conceptual corresponde a la verdad prístina del mundo ideal que el carpintero interpreta para reproducir materialmente su objeto, que no es más que un referente. El pintor que traza su idea de cama sobre un fresco, por

10 Es particularmente interesante el hecho de que en Homero no aparezca en los versos una indicación directa sobre cuándo deja de hablar el poeta y cuándo comienza a hablar la Musa, que es invocada, como sabemos, al comienzo de «Ilíada» y también de «Odisea».

11 Teognis (1931), vv. 367-370.

12 Cf. Platón, 597b-598d. 
su parte, se aleja aún más de esta verdad en la medida que no satisface todas las expectativas del concepto en cuestión; difícilmente alguien podría recostarse sobre una pintura mural.

Sócrates está preocupado por la formación cultural y ética de los futuros ciudadanos que conformarán la comunidad política. Y es que en su memoria resuena el caso de Pisístrato, tirano que gobernó la ciudad de Atenas unos cien años antes, y que hábilmente, supo utilizar el potencial persuasivo de los actos miméticos para legitimar su autoridad.

El año 561 a.C., Pisístrato declaró ante su pueblo que había sido víctima de un ataque propiciado por algunos miembros de la aristocracia y de que se salvó por milagro. Uno de sus partidarios propuso que se le concediera una guardia personal para protegerlo, y la asamblea de ciudadanos le entregó cincuenta hombres armados con garrotes, perpetrando con ellos un golpe de Estado a los pocos días. Sin embargo, este primer gobierno sería efímero pues la alianza de sus adversarios le forzó a abandonar el poder al cabo de un año y debió partir al exilio ${ }^{13}$.

La crisis política y social en Atenas se agudizó al poco tiempo, y las mismas familias aristócratas que antes habían expulsado a Pisístrato, fueron a implorarle que retomara el mando de la nación. Habiendo llegado a un acuerdo, las partes idearon un plan de restauración política que en palabras de Heródoto "era el más grosero artificio que pudiera imaginarse, mayormente si se observa que los griegos siempre fueron considerados más astutos que los bárbaros y menos expuestos a deslumbrarse ante tales necedades, y de que se trataba de engañar a los atenienses, reputados como los más sabios y perspicaces de entre los griegos" 14 .

Pisístrato y sus aliados contactaron a una agraciada doncella que sobresalía del resto de mujeres por su alta estatura. El plan consistía en disfrazarla con los atuendos propios de Atenea, montarla en un lujoso carro junto al depuesto tirano, e ingresar en la ciudad por sorpresa, persuadiendo al pueblo de que su diosa tutelar ahora estaba favoreciendo a Pisístrato. Desde nuestra perspectiva moderna, influenciados por muchos siglos de pretensión

13 Cf. Heródoto, I, 59-60.

14 Heródoto, I, 60. 
racional y escepticismo sobre las cuestiones de orden místico, podríamos aventurarnos en decir que la estrategia estaba condenada al fracaso; incluso Heródoto manifiesta su asombro ante el nivel de superchería del hecho. Para aquellos tiempos arcaicos, sin embargo, era un suceso perfectamente plausible: los conjurados, de tal modo, cumplieron exitosamente su cometido.

Considerando que Sócrates y sus discípulos eran grandes conocedores de la historia de Atenas, no resulta descabellado relacionar la crítica hacia la producción mimética expuesta en «República», con los acontecimientos que dieron lugar a la tiranía de Pisístrato. En efecto, en el segundo capítulo del texto, Sócrates se pregunta sobre la excelencia de los dioses, y concluye que como son entidades perfectas, no necesitan modificar su apariencia. Si acaso decidieran hacerlo -porque ningún factor externo a ellos puede obligarlos a transformarse-, forzosamente tendría que ser para empeorar la figura propia, y al hacerlo, dejarían de ser perfectos. Por lo tanto, "que ningún poeta nos hable de que los dioses toman varias figuras, y que recorren a veces las ciudades en forma de peregrinos errantes...ni nos vengan con similares patrañas" 15 .

Y es que los poetas -y por añadidura, todos los demás artistas que recurren a temas de la tradición épica- han propugnado durante siglos la imagen de la transfiguración dios-mortal ${ }^{16}$, idea contraproducente para la educación de los futuros ciudadanos según pensaba el filósofo.

La mímesis mágica "puede causar estragos en la mente de aquellos que no tienen como contraveneno el conocimiento de su verdadera índole.” ¿Cuál sería esta cualidad fundamental?

Su carácter aparente, la simulación, la imitación, la representación, el como si pero no el ser; todos conceptos que hoy ocupamos como sinónimos de una palabra extremadamente compleja, y que por sí solos no dan cuenta del devenir histórico que ha tenido el término mímesis.

15 Platón, 381d.

16 Cf. Homero (1919), XVII, vv. 485-486. 


\section{Aristóteles y la mímesis como estrategia propedéutica.}

A diferencia de su mentor, Aristóteles reconocía ventajas en la producción mimética. Mientras que la mímesis para Platón no es más que una representación de un referente ideal, por lo tanto, se ubica debajo en el estatuto ontológico, Aristóteles invierte la perspectiva; es decir, precisamente lo importante es la identificación que se produce con la otredad referida, porque así "aprendemos y deducimos lo que cada objeto es, como que esto es aquello"17.

De esta manera, no sería necesario, por ejemplo, que los niños se enfrentaran con animales feroces en los campos para que conozcan el peligro que implica estar próximos a ellos; bastaría con mostrarles una ilustración que los representase y junto con esto, indicarles que las bestias pueden reaccionar violentamente contra la integridad humana si ingresamos en su hábitat natural.

El Estagirita asume que la entidad original es fundamental, y que sin ella, el binomio quedaría incompleto. Sin embargo, su epistemología está basada en la materialidad y en la utilidad de las representaciones como recurso propedéutico: ésta es la función política de la mímesis, y tal vez, la más importante.

Aristóteles no ignoraba el sentido de mímesis como encarnación, ni tampoco desdeñó esta acepción en su obra. En «Poética», el filósofo señala: "la poesía épica y trágica, y la comedia, y el ditirambo, la pintura y la escultura, la danza, y la música de la flauta y la cítara pueden considerarse todas ellas artes miméticas" ${ }^{\prime 18}$. Pero si la pintura imita cuerpos y objetos, y la danza puede imitar gestos y actitudes, cabe preguntarse, ¿qué imita la música de las cuerdas pulsadas? ¿Por qué Aristóteles la considera mímesis? La respuesta aparece en el octavo capítulo de «Política», cuando justifica moralmente la educación musical de los jóvenes: "en las melodías, en sí, hay mímesis de los estados del carácter...Respecto a algunas [escalas], los oyentes se sienten más tristes y más graves... ante otras, sienten más lánguida su mente... y en otros casos...se inspira el entusiasmo"19. Las melodías encarnan conductas en nuestra psiquis

17 Aristóteles, 1448b.

18 Ibíd., 1447a.

19 Aristóteles, 1340a-1340b.

(*) NOTA: "Mímesis" y "mimetizar" son sintagmas originales que utilizan los autores 104 
que se manifiestan, por ejemplo, en la disposición intelectiva y/o en la actitud kinésica que adquirimos según la sucesión de sonidos y ritmos.

Quedaría tanto por decir respecto a la mímesis del teatro y el tema de la catarsis. Baste por ahora lo que se ha dicho, por cuanto he querido remitirme aquí sobre los orígenes históricos del término en cuestión y tensionar su etimología con las nociones modernas que se tornan insuficientes en el análisis de la producción artística presocrática.

griegos aquí citados en sus textos, y que además, aparecen incorporados en el Diccionario de la Real Academia de la Lengua Española. 


\section{REFERENCIAS BIBLIOGRÁFICAS}

ARISTÓTELES. (2006). Poética. Venezuela: Monte-Ávila Editores, - (2007). Política. Barcelona: Gredos.

BOCHETTI, C. (2006). El espejo de las Musas. Santiago: Centro de Estudios Griegos, Bizantinos y Neohelénicos Universidad de Chile.

BOZAL, V. (1987). Mimesis: las imágenes y las cosas. Madrid: Visor.

CHIC, G. (2009). El comercio y el Mediterráneo en la Antigüedad. Madrid: Akal.

HERÓDOTO. (2010). Los nueve libros de la Historia. Madrid: Aleph. HOMERO. (1919). Odyssey. Londres: Harvard University Press.

- $\quad$ (1914). The Homeric Hymns. Londres: Harvard University Press.

JAEGGER, W. (2000). Paideia: los ideales de la cultura griega. México: FCE. PLATÓN. (2010). La República. Madrid: Alianza.

RUCK, C.et al. (1980). El camino a Eleusis: una solución al enigma de los misterios. México: FCE.

TEOGNIS. (1931). Elegy and Iambus. Londres: Harvard University Press. 